\title{
FACING SOLO RAYA METROPOLITAN CITY: ANALYSIS OF THE DEVELOPMENT PLANNING
}

\author{
${ }^{1}$ Rita Noviani, ${ }^{2}$ Lutfi Muta'ali, ${ }^{3}$ Nasruddin \\ ${ }^{1,2}$ Universitas Gajah Mada \\ ${ }^{3}$ Universitas Lambung Mangkurat \\ e-mail : ritanoviani253@yahoo.com
}

\begin{abstract}
Since 2010 Solo Raya has became part of the metropolis candidates that will continue to grow along with the agglomeration of Jogjakarta and Semarang. The problems that trail is the tendency of metropolitan magnitude that resulted in less functioning of the city as a catalyst for regional development. Further impact is the lagging of small and medium-sized cities (Tjahjati, 1995). The development of urban system is determined by both the comparative advantage and the competitive advantages, such as location, natural resources and human resources (Metropolitan Directorate, 2003), so that in planning the development it should focus on the ability to cooperate or synergize between regions (spatial synergism) either in urban and rural area or on a wider scale, cooperation between cities.

The purpose of this research was to arrange aspects and decision criteria in developing metropolitan area of Solo Raya. The method used is literature study approach which is then analyzed descriptively.

The result of analysis showed that in metropolitan area of the world there are 4 (four) main characteristics and problems, they are: (1) city as center of population, economy and government activity, (2) city with environmental problems (air, land and water), as a result of population density, public transportation, and garbage, (3) city with problems in the land aspect (land prices and housing provision) and (4) city with problems on social aspects (criminals and terrorists). The formulation of metropolitan area development planning is done with 3 (three) considerations, they are: (1) avoiding high social segregation between and among regions, (2) creating a balance population mobility and intra and inter-regional services (spirit of togetherness), (3) creating a regional economy (growth, equity and welfare) based on the local potential which has inter-regional connectivity (harmonization). Aspects and criteria are: regional management (spatial planning policy, regional competitiveness, regional marketing, inter-regional cooperation), urbanization (migration, urbanization, agglomeration and conurbation, social integration), economic development (economic growth, employment, economic equalization, urban poverty), regional connectivity (transportation, rural-urban linkage, territorial function), and environment (environmental supporting capacity, disaster risk, environmental degradation, disaster mitigation). The decision priorities include: Industrial City, Service City, City of Tourism and Culture, Trade City, and Agriculture.
\end{abstract}

Keywords: Aspect and Criteria of Decision, Solo Metropolitan City

\section{A. Introduction}

Since 2010 Solo Raya has became one of the metropolitan candidates that will continue to grow along with the agglomeration of Jogjakarta and Semarang. The problems that accompany the phenomenon is the tendency of metropolitan magnitude that resulted in less functioning of the city as a catalyst for regional development. Further impact is the lagging of small and medium-sized cities (Tjahjati, 1995). The development of urban system is determined by both the comparative advantage and the competitive 
advantages, such as location, natural resources and human resources (Metropolitan Directorate, 2003), so that in planning the development, it needs to focus on the ability to cooperate or synergize between regions (spatial synergism) either in urban-rural or on a wider scale, cooperation between cities.

Marketing is interpreted as a social activity involving the relationship between producers and consumers. According to Kotler (2009), marketing is defined as a social and managerial process undertaken by individuals and groups in order to meet needs and wants through a process of creating and exchanging products and values with others. Thus, the main essence of the marketing process is the effort of creating consumer satisfaction by producers through the creation and exchange of things. Regional marketing is an aspect of urban management (Nelissen, 1998 in Ashworth and Voogd, 1990). Regional marketing is an awareness to attract private investment to realize the dream of a city plan (Pumain, 1989 in Ashworth and Voogd, 1990).

Regional marketing in essence implements activities developed on the basis of four fundamental activities of developing strong and attractive regional positioning and image, determining attractive incentives for current customers and potential customers, delivering products and services in the form of a region that can be efficiently carried out, promoting regional attractiveness and benefits to ensure that customers and potential customers are fully aware of the advantages possessed by the region. In order to achieve the effectiveness of regional marketing activities, marketers and local governments need to understand and pinpoint the target market with the aim of making the region consisting of local governments and communities into hosts capable of serving and meeting the needs and wants of the target market (Kotler and Armstrong 2008).

One of the strategies in regional development to bring benefits is by regional branding. Regional branding is a strategy to create a strong positioning in the target market, so that the area can be widely known (A. Noe'man, 2008; Handani, 2010). One region that uses regional branding is the region of SUBOSUKAWONOSRATEN consisting of 6 (six) areas (Surakarta City, Boyolali District, Sukoharjo District, Karanganyar Regency, Wonogiri Regency, Sragen Regency and Klaten Regency) better known as Solo Raya area. 


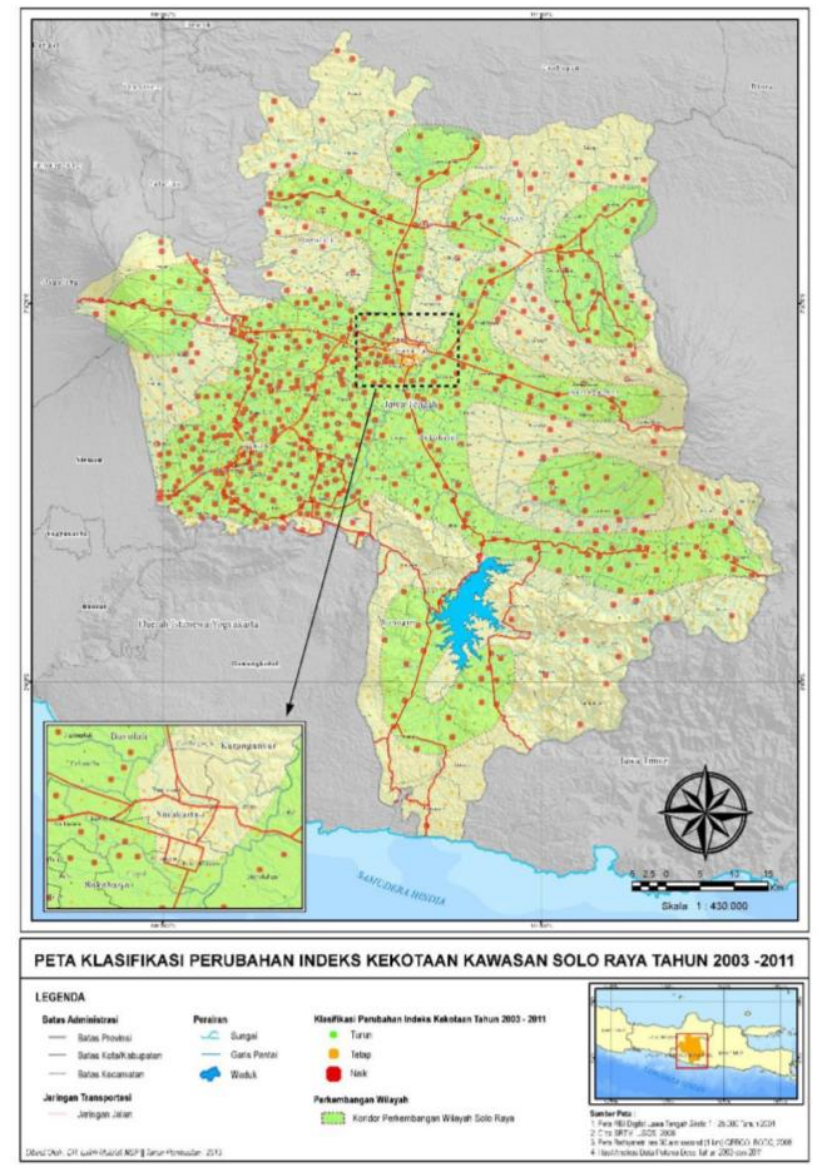

Figure 1. Map of Index Change Classification of the Solo Raya Area 2003-2011

Solo Raya, besides as a regional branding, in the perspective of the region is a regional entity that includes urban systems and rural systems that interact to form a relationship between the city of Surakarta and surrounding districts in accordance with their respective roles. The area of Solo Raya has a strategic location, that is as a central and is part of Joglosemar development area that combines Yogyakarta, Solo and Semarang. Solo Raya is located not far from major trading centers in Central Java and East Java. It is about $102 \mathrm{~km}$ from Semarang, $60 \mathrm{~km}$ from
Yogyakarta and about $210 \mathrm{~km}$ from Surabaya. All of these areas can be reached easily from Solo Raya because the roads and tracks are in good condition covering an area of 5,722.38 $\mathrm{km}^{2}$ (Handani, 2010).

The development of the Solo Raya area as a city system tends to concentrate in the city of Surakarta and has not provided a proportional role for the surrounding district (Sukoharjo, Klaten, Karanganyar, Sragen, Wonogiri and Boyolali). This developmental tendency has a negative effect on the development of the city of Surakarta itself, as well as other districts. 
The configuration of the city system in Solo Raya region grows and develops with different directions and magnitudes. The results of early Surakarta study showed symptoms of primacy or centralization of urban development. Differences in the function and role of each city should not be a competitor to other cities, but can support each other and equip one to another (Noviani, 2011).

\section{B. Methods}

The research method used in this paper is descriptive narrative with literature study obtained from deepening of textbook, research result, journal, and seminar.

\section{Results}

\section{Characteristics of the World Metropolitan Area}

Understanding the metropolitan area can not be easily defined only by population size, because there are cities with smaller populations but larger areas; there are cities with larger populations with smaller towns, and there are cities with smaller populations but with a striking urban character. The metropolitan characters are not the same in the world, this is mainly due to different histories as well as different economic developments. Angotti (1993) distinguishes the metropolis in the world into three types, namely the Metropolitan in the US (US Metropolis), Metropolitan city which is not independent (Dependent Metropolis) and Metropolitan in the Soviet Union (Soviet Metropolis). This division is more influenced by the approach of political economy. The Metropolitan in America (as well as Europe) is a reflection of the capitalist economy, the Metropolitan in the former Soviet Union is a picture of the socialist economy, while the Dependent Metropolis is a picture of a mixed economy. History of the development of metropolitan concepts in the world is related with the development of the metropolitan areas which is divided into 3 (three): in developed countries, in socialist countries and in the developing countries. The development of metropolitan in developed countries, Rydin (1993) explains, is formed because of the economic agglomeration that caused the city's economic dominance to its periphery. The industrial revolution has caused cities like London to be a place of industrial development and urbanization from village to town which has risen sharply. Between 1821 and 1851, or in just 30 years, the population of London has increased by 4 million. Anggotti (1993) explains that the figure is very high in the context of Europe at the time. Growth is often seen as 
"colonization" of the city against its periphery or even against rural areas.

Montgomery et al. (2003), in their study in Mexico City, explains that there has been an amalgamation of several urban areas into a large area within the federal district by including several administrative regions and forming it into a metropolitan area with a population of 17.9 million. Urban areas that cross administrative boundaries require good management cooperation between the administrative regions forming the large area. Some major cities in the world have inter-regional cooperation that is shown in formal institutions that have certain authority in the management and planning of urban service facilities. The metropolitan structure may in fact have one center (monocentric) or more than one center (polycentric). In a polycentric metropolis, metropolitan centers do not have to be physically connected in the form of a built-up area, in contrast to the notion of conurbation, the metropolitan cities of polycentric are connected economically and physically, and as a whole to a big urban area. Examples of such polycentric forms are Tokyo-Kawasaki Yokohama (the Keihin Zone), or Osaka-Kobe and Kyoto as Kehanshin Zone. If metropolitan areas are so close together, they can form a Megalopolis.

Table 1. Characteristics of World Metropolitan

\begin{tabular}{|c|c|c|c|}
\hline No & $\begin{array}{c}\text { Metropolitan } \\
\text { Area }\end{array}$ & Characteristics & Problems \\
\hline 1 & US Metropolis & $\begin{array}{l}\text { Key Features of Capitalist Economy } \\
\text { (inequality dan mobility) } \\
\text { 1. High social and spatial segregation } \\
\text { 2. Fragmentation in ethnic groups and } \\
\text { political groups characterized by a very } \\
\text { strong Central Business District (CBD) } \\
\text { which attracts workers. }\end{array}$ & $\begin{array}{l}\text { New York Case: } \\
-\quad \text { Formation of urban sprawl } \\
\text { symptoms } \\
-\quad \text { High population density } \\
-\quad \text { High energy consumption } \\
-\quad \text { Large commuters which } \\
\text { generate pollution, congestion, } \\
\text { traffic, frustration or stress due } \\
\text { to traveling a great distance. } \\
\text { The large number of } \\
\text { commuters due to the spread of } \\
\text { suburban areas that are housing } \\
\text { areas, while the workplace is } \\
\text { located in the center of the city }\end{array}$ \\
\hline 2 & $\begin{array}{l}\text { Dependent } \\
\text { Metropolis }\end{array}$ & $\begin{array}{l}\text { Key Features of Blended Economy } \\
\text { (development dan inequality) } \\
\text { 1. Population growth and great } \\
\text { urbanization resulting from push factor } \\
\text { 2. Industrial Revolution (European } \\
\text { Region), City as industrial center }\end{array}$ & 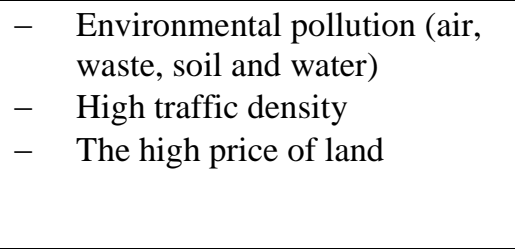 \\
\hline
\end{tabular}




\begin{tabular}{|c|c|c|c|}
\hline No & $\begin{array}{c}\text { Metropolitan } \\
\text { Area }\end{array}$ & Characteristics & Problems \\
\hline & & $\begin{array}{l}\text { 3. The city as the center of power and } \\
\text { territory of European Colonization } \\
\text { (Latin America and Africa, and Asia) } \\
\text { 4. City as a trading center (Manila, } \\
\text { Mumbai, Calcutta, Seoul) }\end{array}$ & \\
\hline 3 & $\begin{array}{l}\text { Soviet } \\
\text { Metropolis }\end{array}$ & $\begin{array}{l}\text { Key Feature of Socialist Economy } \\
\text { 1. Social integration and more limited } \\
\text { political structure } \\
\text { 2. Low social mobility } \\
\text { 3. Concentric radial space structure } \\
\text { (Moscow) }\end{array}$ & $\begin{array}{l}\text { Case of Moskow city: } \\
-\quad \text { Environmental pollution (air, } \\
\text { waste, soil and water) } \\
-\quad \text { Crime and terrorist acts } \\
\text { Case of Shanghai city: } \\
-\quad \text { The availability of clean water } \\
\text { and water pollution } \\
-\quad \text { House provision }\end{array}$ \\
\hline
\end{tabular}

Source: Angotti, 1993 (processed)

Based on Angotti (1993) in Table 1 above, it can be concluded that there are 4 (four) main features and problems in the metropolitan area, they are:

1) City as the center (concentric) of the population activities, economic activities and government activities

2) City with environmental problems (air, land and water), as a result of population density, public transport, and garbage.

3) City with problems in the land aspect (land prices and housing provision)

4) City with problems on social aspects (criminals and terrorists).

Goheen (in Bourne, ed. 1971), explains that metropolitan cities/districts are urban areas with prominent population characteristics compared to the surrounding rural population. This term is used to provide a more precise description of the magnitude and concentration of the population in a large area, which can then show the magnitude of major settlement centers in one country. In general, the metropolitan area can be defined as a region with a large population concentration, with integrated economic and social unity and characterizing urban activity.

Specific impact on the environment of the metropolitan area, as Rosan et al (2000) notes, is that about 30 percent of urban population in developing countries do not have access to clean water, and 50 percent do not have good sanitation systems, which are seen in slum and squatter settlements. This is in line with UN Habitat (2006) which shows that 64 percent of the slum environment were in Asian countries, with very poor circumstances. The situation is, according to some opinions, one of the causes of conflict in urban areas (Winarso et al., 2002). The big cities face economic problems, especially in providing formal employment 
opportunities for their communities. Metropolitan also faces environmental problems. The environmental quality has decreased markedly from the level of pollution in these cities due to traffic congestion and poor public transport system and reduced water absorption caused by urban spatial arrangement (Rosan et al., 2000).

\section{Criteria for Development Policy of}

\section{Solo Raya Metropolitan City}

The development of Solo Raya

Metropolitan area has been initiated by 8
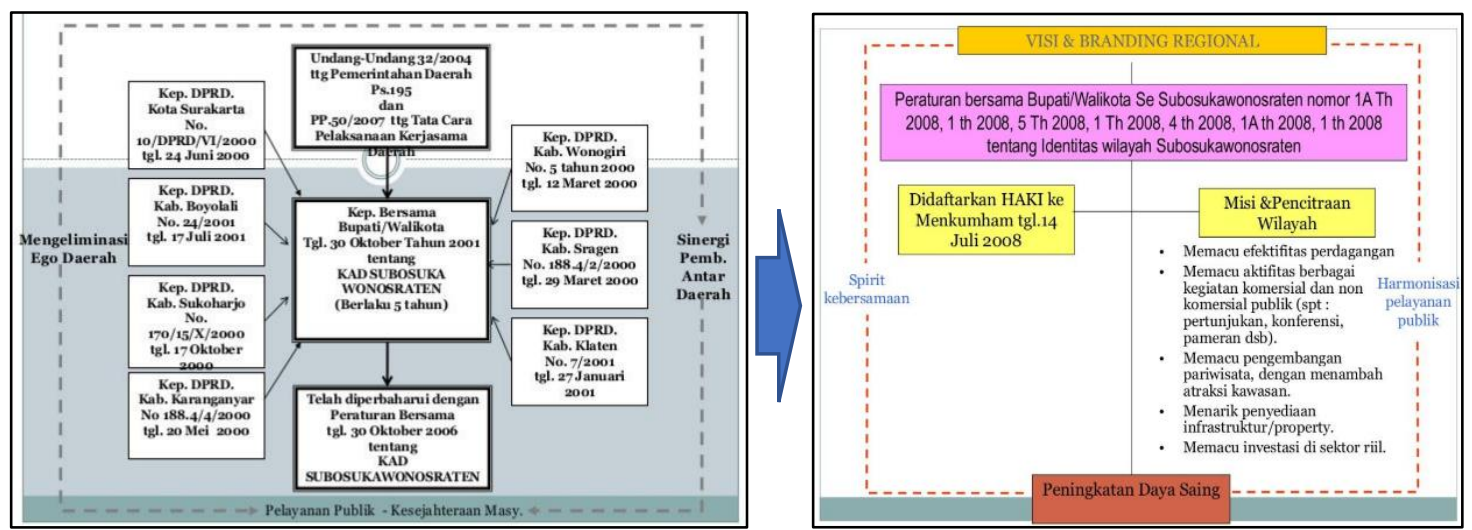

Figure 2. Basic Establishment of Inter-Regional Cooperation Solo Raya (Source: BKAD SUBOSUKAWONOSRATEN, 2014)

The cooperation scope of Solo Raya Metropolitan

(SUBOSUKAWONOSRATEN) covers the fields of economy, culture, social, health, physical and infrastructure, development of science and technology and other fields. The cooperation is in order to establish the spirit of togetherness, harmonization of public services in order to improve the (eight) regions through the Inter-regional Cooperation Agency known as SUBOSUKAWONOSRATEN (Surakarta City, Boyolali District, Sukoharjo Regency, Karanganyar Regency, Wonogiri Regency, Sragen Regency and Klaten Regency), as stated in the decision of the district heads on October 30, 2001 in an Inter-Regional Cooperation, with the function to eliminate the regional ego, synergize the regional development, with the main objective of public service for the welfare of the community. 
Considering the metropolitan characteristics of the world and its problems as well as the cooperation among SUBOSUKAWONRATEN regions which allows the formation of metropolitan area, then compiled several criteria, aspects and priorities in the development of metropolitan area of Solo Raya, with several main considerations:

1) avoiding high social segregation in and among regions,
2) creating a balance of population mobility in and inter-regional services (spirit of togetherness), and

3) creating a regional economy (growth, equity and welfare) based on the local potential that have inter-regional connectivity (harmonization).

Based on 3 (three) considerations above, it was set aspects, criteria and priorities in the development of Solo Raya metropolitan, as in Table 2.

Table 2. Aspects, Criteria and Priorities of Solo Raya Metropolitan Development

\begin{tabular}{|c|c|c|c|}
\hline No & Aspect & Criteria & Priority \\
\hline \multirow[t]{4}{*}{1} & Districts & 1. Spatial Planning Policy & \multirow{20}{*}{$\begin{array}{ll}\text { 1. } & \text { Industrial City } \\
\text { 2. Service City } \\
\text { 3. City of Tourism and Culture } \\
\text { 4. Trade City } \\
\text { 5. Agriculture }\end{array}$} \\
\hline & Manajemen & 2. Regional Competitiveness & \\
\hline & & 3. Regional Marketing & \\
\hline & & 4. Inter-regional Cooperation & \\
\hline \multirow[t]{4}{*}{2} & Urbanization & 1. Migration & \\
\hline & & 2. Urbanization & \\
\hline & & 3. Agglomeration and conurbation & \\
\hline & & 4. Social Integration & \\
\hline \multirow[t]{4}{*}{3} & Economic & 1. Economic Growth & \\
\hline & Development & 2. Employment Opportunities & \\
\hline & & 3. Equalization of the economy & \\
\hline & & 4. Urban Poverty & \\
\hline \multirow[t]{3}{*}{4} & Districts & 1. Transportation & \\
\hline & Connectivity & 2. Rural-Urban Linkage & \\
\hline & & 3. Territorial Function & \\
\hline \multirow[t]{5}{*}{5} & Environment & 1. Environmental Supporting & \\
\hline & & Capacity & \\
\hline & & 2. Disaster Risk & \\
\hline & & 3. Environmental Degradation & \\
\hline & & 4. Disaster Mitigation & \\
\hline
\end{tabular}




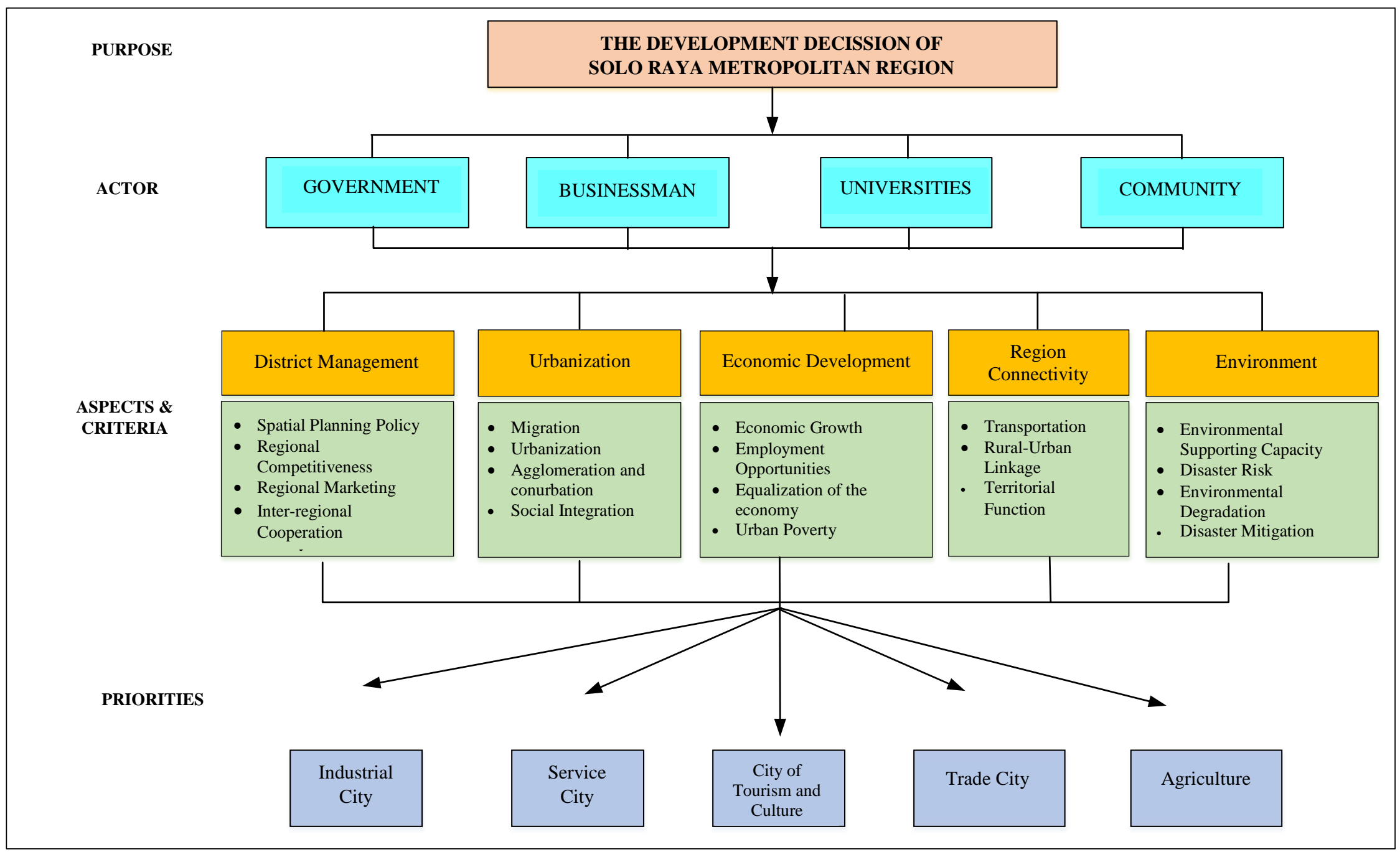

Figure 3. Development Decision Structure of Solo Raya Metropolitan Area 


\section{Conclusion and Recommendation}

Based on the discussion above, it can be concluded that:

1) There are 4 (four) main features and problems in the metropolitan area of the world, they are: (1) city as center (concentric) of population, economy and government activity, (2) city with environmental problems (air, land and water), as a result of population density, public transportation, and garbage, (3) city with problems on land aspects (land prices and housing provision), and (4) city with social (criminal and terrorist) issues.

2) The main considerations in the development decision of Solo Raya metroplitan area are (1) avoiding high social segregation in and among regions, (2) creating a balance of population mobility and in and interregional services (spirit of togetherness), (3) creating a regional economy (growth, equity and welfare) based on the local potential that have inter-regional connectivity (harmonization).

3) The aspects and criteria in the development decision of Solo Raya metroplitan area are: regional management (spatial planning policy, regional competitiveness, regional marketing, inter-regional cooperation), urbanization (migration, urbanization, agglomeration and conurbation, social integration) economic development (economic growth, employment, economic equality, urban poverty), regional connectivity (transportation, rural-urban linkage, territorial function), and environment (environmental supporting capacity, disaster risk, environmental degradation, disaster mitigation). The decision priorities include: Industrial City, Services City, City of Tourism and Culture, Trade City, and Agriculture.

Recommendations from the results of this study are as follows:

1) The need to be followed up through further research activities involving stakeholders in the Solo Raya metropolitan development area (SUBOSUKAWONOSRATEN) with analysis of decision support systems.

2) The importance of reconstruction in the aspects, criteria and priorities of the development policy of Solo Raya metropolitan

(SUBOSUKAWONOSRATEN), by looking at the metropolitan problems in the world. 


\section{REFERENCES}

Angotti, T. (1993). Metropolis 2000, Planning, Poverty and Politics. New York: Routledge.

Ashworth, G.J., \& Voogd, H. (1990). Selling the City: Marketing Approaches in Public Sector Planning-Urban Planning. London: Belhaven Press

Badan Kerjasama Antar Daerah (BKAD). (2014). Kerjasama Antar Daerah Sebagai Payung Pengembangan Ekonomi Lokal Daerah, Presentation on 'Workshop and Implementation Study of Reinforcement Regional Management in Local Economic Disanvantaged Regions for Bilateral Partnership Sinergy Program KPDT, Bappenas dan GIS-RED', Solo 7 October 2014.

Bourne, Larry S (ed). (1971). Internal Structure Of The City. New York, Oxfrord University Prees.

Kotler, P (1999). Marketing Places Europe: Attracting Investment, Industries, Resident and Visitors to European Cities, Communities, Regions and Nations. London: Pearson Education.

Kotler, P \& Amstrong (2008). Marketing Asian Places: Attracting Investment, Industry, and Tourism to Cities,
States, and Nations. Singapore: John Wiley \& Sons, Inc.

Handini, K. (2010). Regional Branding "Solo the Spirit of Java" (Suatu Tinjauan dari Aspek Hak Kekayaan Intelektual). Law Magister Program Thesis of Diponegoro University. Unpublished

McGee, T.G. (1987). Urbanisasi or Kotadesasi: The Emergence of New Regions of Economics Interaction in Asia. Honolulu Environment and Policy Institut, pp. 93-108. (1997). The Emergences of DesaKota Regions in Asia : Expanding a Hypothesis. In The Extended Metropolis and Settlement Transsition in Asia. The University of Hawaii Press: Honolulu.

McGee, T.G., Ginsburg, N.S., and Koppel, B. (1991). The Extended Metropolis: Settlement Transition in Asia. The University of Hawaii Press: Honolulu Montgomery, Stren, Cohen, \& Reed. (2003). Cities Transformed Demographic Change and Its Implication in the Developing World. Washington, D.C: The National Academies Press.

Riyadi, D.S. (2002). Pengembangan Wilayah, Teori dan Konsep Dasar, Prosiding Pengembangan Wilayah 
dan Otonomi Daerah, Jakarta: Pusat

Pengkajian Kebijakan Teknologi

Pengembangan Wilayah, Deputi

Pengkajian Kebijakan Teknologi,

Badan Pengkajian dan Penerapan

Teknologi.

Riyadi. (2009). Fenomena City Branding Pada Era Otonomi Daerah. Jurnal Bisnis dan

Kewirausahaan, Vol. 5 No.1, Maret 2009 Hal-1.

Rosan, C., Ruble, B.A., Tulchin, J.S. (2000). Urbanization, Population, Environment, and Security. Washington, DC: The Woodrow Wilson International Center for Scholars.

Rydin, Y. (1993). The British Planning System-An Introduction. London: Macmillan.

Situmorang, S.H. (2008). Destination Brand: Membangun Keunggulan en Teknik Planologi ITB.
Bersaing Daerah. Wahana Hijau Jurnal Perencanaan \& Pengembangan Wilayah, Vol.4, No.2,

Desember 2008

Tjahjati, Budhy. (1995). Kebijaksanaan Pembangunan Perkotaan di Indonesia. Jurnal PWK-ITB Tahun 1995. Bandung.

U.N. HABITAT. (2006). The State of the World's Cities Report 2006/2007. The Millennium Development Goals and Urban Sustainability: 30 Years of Shaping the Habitat Agenda. London: Earthscan

Winarso, Pradono, Zulkaidi, \& Miharja. (2002). Pemikiran dan Praktek Perencanaan dalam Era Transformasi di Indonesia. Bandung: Departem 